\title{
The Prevalence and Characterization of Self-Medication for Obtaining Pain Relief Among Undergraduate Nursing Students ${ }^{1}$
}

\author{
Layz Alves Ferreira Souza ${ }^{2}$ \\ Camila Damázio da Silva ${ }^{3}$ \\ Gisely Carvalho Ferraz ${ }^{4}$ \\ Fátima Aparecida Emm Faleiros Sousa ${ }^{5}$ \\ Lílian Varanda Pereira ${ }^{6}$
}

\begin{abstract}
This study investigates the prevalence of self-medication among undergraduate nursing students seeking to relieve pain and characterizes the pain and relief obtained through the used medication. This epidemiological and cross-sectional study was carried out with 211 nursing students from a public university in Goiás, GO, Brazil. A numerical scale (0-10) measured pain intensity and relief. The prevalence of self-medication was $38.8 \%$. The source and main determining factor of this practice were the student him/herself $(54.1 \%)$ and lack of time to go to a doctor $(50 \%)$, respectively. The most frequently used analgesic was dipyrone $(59.8 \%)$ and pain relief was classified as good $(M d=8.5 ; \operatorname{Max}=10 ; \operatorname{Min}=0)$. The prevalence of self-medication was higher than that observed in similar studies. Many students reported that relief obtained through self-medication was good, a fact that can delay the clarification of a diagnosis and its appropriate treatment.
\end{abstract}

Descriptors: Pain; Self Medication; Students, Nursing.

${ }^{1}$ This research was supported by Conselho Nacional de Desenvolvimento Científico e Tecnológico (CNPq).

2 Undergraduate student in Nursing, Faculdade de Enfermagem, Universidade Federal de Goiás, GO, Brazil. Scholarship holder of the Scientific Initiation Program at the Conselho Nacional de Desenvolvimento Científico e Tecnológico (CNPq). E-mail: layzenf@gmail.com.

${ }^{3}$ RN, Centro de Atenção Integral à Saúde de Campinas, Goiânia, GO, Brazil. E-mail: camiladamazio7@hotmail.com.

${ }^{4}$ RN. E-mail: gisely_ferrazz@yahoo.com.br.

${ }^{5}$ RN, Ph.D. in Nursgin, Full Professor, Escola de Enfermagem de Ribeirão Preto, Universidade de São Paulo, WHO Collaborating Centre for Nursing Research Development, SP, Brazil. E-mail: faleiros@eerp.usp.br.

${ }^{6}$ RN, Ph.D. in Nursing, Escola de Enfermagem de Ribeirão Preto, Universidade de São Paulo, WHO Collaborating Centre for Nursing Research Development, SP, Brazil, Faculdade de Enfermagem, Universidade Federal de Goiás, GO, Brazil. E-mail: Ivaranda@terra.com.br.

\footnotetext{
Corresponding Author:

Lílian Varanda Pereira

Universidade Federal de Goiás. Faculdade de Enfermagem.

Rua 227, Quadra 68, s/n

Setor Leste Universitário

CEP: 74605-080 Goiânia, GO, Brasil

E-mail: Ivaranda@terra.com.br
} 


\title{
Prevalência e caracterização da prática de automedicação para alívio da dor entre estudantes universitários de enfermagem
}

Os objetivos deste estudo foram: estimar a prevalência de automedicação entre estudantes universitários de enfermagem com dor e caracterizar a experiência dolorosa e o alívio obtido, por meio dos fármacos utilizados. É estudo epidemiológico seccional, do qual participaram 211 estudantes de uma universidade pública de Goiás, Brasil. A dor e o alívio foram medidos por meio de escala numérica (0-10). A prevalência de automedicação foi de $38,8 \%$. A fonte geradora e o fator determinante prevalentes dessa prática foram o próprio estudante $(54,1 \%)$ e a falta de tempo para ir ao médico $(50 \%)$, respectivamente. A dipirona foi o analgésico mais utilizado $(59,8 \%)$ e o alívio da dor classificado como bom ( $M d=8,5 ;$ máx=10; mín=0). A prevalência da automedicação foi maior do que aquela observada em estudos semelhantes e, para muitos estudantes, o alívio foi bom, fato que pode retardar a elucidação do diagnóstico e o tratamento adequado da dor.

Descritores: Dor; Automedicação; Estudantes de Enfermagem.

\section{Prevalencia y caracterización de la práctica de automedicación para alivio del dolor entre estudiantes universitarios de enfermería}

\begin{abstract}
Los objetivos de este estudio fueron estimar la prevalencia de automedicación entre estudiantes universitarios de enfermería con dolor y caracterizar la experiencia dolorosa y el alivio obtenido por medio de los fármacos utilizados. Se trata de un estudio epidemiológico seccional, del cual participaron 211 estudiantes de una universidad pública de Goiás, en Brasil. El dolor y el alivio fueron medidos por medio de una Escala Numérica (0-10). La prevalencia de automedicación fue de 38,8\%. La fuente generadora y los factores determinantes prevalentes de esta práctica fueron el propio estudiante $(54,1 \%)$ y la falta de tiempo para ir al médico $(50 \%)$, respectivamente. La dipirona fue el analgésico más utilizado $(59,8 \%)$ y el alivio del dolor clasificado como bueno $(M d=8,5 ; M a ́ x=10 ; M i ́ n=0)$. La prevalencia de la automedicación fue mayor que aquella observada en estudios semejantes y para muchos estudiantes el alivio fue bueno, hecho que puede retardar la elucidación del diagnóstico y del tratamiento adecuado del dolor.

Descriptores: Dolor; Automedicación; Estudiantes de Enfermería.
\end{abstract}

\section{Introduction}

Self-medication consists of the use of manufactured or homemade drugs without a medical prescription seeking to treat symptoms or self-diagnosed health conditions(1). According to the World Health Organization (WHO), informed self-medication is a way to self-care. Qualified professionals, preferably pharmacists, should encourage the rational use of medication, provide information on drugs and complications that may result from their indiscriminate use and refer people to medical care when necessary, promoting responsible self-medication(2).
Pain is among the reasons that people selfmedicate ${ }^{(3-4)}$. People who experience pain seek relief through medical counseling, complementary therapies, and/or self-medication. One study carried out in Spain, in which 1,964 people of both genders between 20 and 91 years of age participated, showed that $66.3 \%$ of the individuals sought medical care when experiencing pain, $27.6 \%$ self-medicated, $20.5 \%$ used alternative therapies and $10.6 \%$ did not treat themselves ${ }^{(5)}$.

The epidemiological profile of self-medication was 
investigated in Brazil in a study conducted with 4,174 individuals, of both genders, aged between 0 and 95 years. It indicated that $17.3 \%$ of the medications used were painkillers, while the main ones used were: dipyrone (7.1\%), acetylsalicylic acid (4.9\%) and paracetamol $(1.4 \%)$. In this same study, $40 \%$ of people who practiced self-medication received guidance from previous prescriptions and $51 \%$ received suggestions from non-qualified people(3).

In a population-based study conducted in Bambuí, MG, Brazil with a random sample of 1,221 residents aged > 18 years, of both genders, 775 participated in the study, of which 223 (28.8\%) took exclusively nonprescribed medication. Among the variables associated with the exclusive use of self-medication the following were highlighted: female gender $(\mathrm{OR}=0.6,95 \% \mathrm{CI}$ 0.4-0.9), and age ( $O R=0.4,95 \% C I=0.3$ to 0.6 and $\mathrm{OR}=0.2,95 \% \mathrm{CI} 0.1$ to 0.5 for $40-59$ and $>60$ years, respectively). The authors concluded that the prevalence of self-medication is similar to that observed in developed countries ${ }^{(6)}$.

In relation to the characterization of pain, studies with populations in general showed that self-medication was prevalent among those reporting acute pain of moderate intensity and headaches ${ }^{(3,5)}$. Similar results were observed when the sample was composed of undergraduate students attending pharmacology, dentistry and nursing programs ${ }^{(4)}$. In other studies, the participants of which were nursing students, self-medication was investigated in relation to the consumption of benzodiazepines(7); however studies addressing self-medication in undergraduate students with pain were not identified.

In this context, we deemed it important to conduct an epidemiological study aiming to contribute to knowledge concerning self-medication in Brazil. It is expected that results will allow identifying the extent of the problem and its characteristics among university students and support programs seeking to improve the health conditions of nursing students.

Therefore, the study's objectives were: to estimate the prevalence of self-medication among nursing undergraduate students with pain and characterize the painful experience and relief obtained through the drugs used.

\section{Method}

This observational study with cross-sectional design was carried out at the Federal University of Goiás, Brazil,
College of Nursing, between March and June 2008. The eligible participants were 250 students aged between 18 and 29 years old, both genders, distributed over the program's five years; 211 students consented to participate in the study. Of these, 196 reported some type of pain (acute or chronic) and were included in the study.

Study variables: the dependent variable was selfmedication, understood as the use of manufactured or non-manufactured products without medical prescription to treat symptoms or self-diagnosed diseases ${ }^{(1)}$. The source (family, friends, drugstore clerk, old medical prescriptions or the student him/herself), the type of medication used (simple analgesics, opioids, nonsteroidal anti-inflammatory drugs [NSAIDs]) and the motives associated with self-medication (lack of access to health services, delays in medical care provided in health facilities, lack of time, disregard for the medical treatment due to failure in relieving pain in previous treatments, the participants' knowledge aided in the choice of a medication, the faster and cheaper access to the drugstore clerk compared to a physician).

The socioeconomic and demographic variables included gender (female and male), socioeconomic class (A1, A2, B1, B2, C1, C2, D, and E - ABA/ABIPEME), age $(18-20,21-23, \geq 24)$, marital status (have a partner/ do not have a partner $)$, and school year $\left(1^{\text {st }}, 2^{\text {nd }}, 3^{\text {rd }}, 4^{\text {th }}\right.$ and $\left.5^{\text {th }}\right)$. The variables related to the painful experience were: site (identified through body diagrams), intensity (measured through a numerical scale from 0 to 10) and duration of pain (pain for three months or more in the same site with episodes every 15 days was considered chronic) ${ }^{(8)}$

Data collection: data were collected by trained observers in classrooms at the Federal University of Goiás, College of Nursing, when students were available an occasion during which they were informed about the study and its objectives.

After the students signed free and informed consent terms, they filled in a specific questionnaire. This study was submitted to and approved by the Research Ethics Committee at the Hospital das Clinicas, Federal University of Goiás, Protocol No 173/2007.

Data Analysis: average, median and mode; minimum, maximum, standard deviation and coefficient of variation; simple and absolute frequencies and percentages were analyzed in numerical variables. All analysis (frequency and descriptive measures) was performed using the Statistical Package for the Social Sciences (SPSS) version 15.0. The results were 
organized into tables. Associations among categorical variables were analyzed based on non-parametrical tests such as Person's Chi-square and Fisher's exact test, and Spearman's coefficient of correlation was used for associations among numerical variables. When the numerical variable presented only two levels, Student's $t$ test or the Mann-Whitney test was used. Normality of data was verified through the Kolmogorov-Smirnov test and homogeneity of variances through the Bartlett test. The level of significance was fixed at $\alpha=5 \%$ in all tests.

\section{Results}

Data showed that $38.8 \%$ of students practiced selfmedication in situations of pain. The participants' age varied from 18 to 29 years old $(A=21$ years; $S D=1.95)$, while most students were women $(96.4 \%)(p<0.001)$ and belonged to the socioeconomic classes $A$ and $B$ $(82.3 \%)$ (Table 1 ).

Table 1 - Distribution of undergraduate students who reported self-medication in situations of pain, considering demographic and socioeconomic data. Goiania, Brazil 2009

\begin{tabular}{|c|c|c|c|}
\hline \multirow{2}{*}{ Variables } & \multicolumn{3}{|c|}{ Undergraduate students } \\
\hline & $\mathbf{n}$ & $(\%)$ & $\mathbf{p}^{*}$ \\
\hline Age range & & & $>0.05$ \\
\hline $18-20$ years old & 29 & 38.2 & \\
\hline 21-23 years old & 40 & 52.6 & \\
\hline$\geq 24$ years old & 7 & 9.2 & \\
\hline Gender & & & $<0.001$ \\
\hline Male & 2 & 2.7 & \\
\hline Female & 74 & 97.3 & \\
\hline School year & & & $>0.05$ \\
\hline $1^{\text {st }}$ & 11 & 12 & \\
\hline $2^{\text {nd }}$ & 17 & 23 & \\
\hline $3^{\text {rd }}$ & 16 & 22 & \\
\hline $4^{\text {th }}$ & 15 & 20 & \\
\hline $5^{\text {th }}$ & 17 & 23 & \\
\hline Socioeconomic class & & & $>0.05$ \\
\hline Class A1 & 12 & 15.8 & \\
\hline Class A2 & 22 & 29 & \\
\hline Class B1 & 14 & 18.5 & \\
\hline Class B2 & 15 & 19.7 & \\
\hline Class C1 & 8 & 10.5 & \\
\hline Class C2 & 2 & 2.6 & \\
\hline Class D & 1 & 1.3 & \\
\hline Class E & 2 & 2.6 & \\
\hline
\end{tabular}

*Chi-square test

The median of scores attributed to intensity of pain measured through a numerical scale (0-10) was 6.0 $(M I N=2 ; M A X=10 ; Q 1=5 ; Q 3=8)$, which permitted to classifying it as moderate $(p=0.05)$. In relation to the pain's site, headaches were prevalent in $51.4 \%$ of the findings $(p<0.005)$. In relation to the duration of the pain, $28.9 \%$ of the students reported they experienced pain from 1 to 5 years, and $69.7 \%$ of those who selfmedicated had chronic pain (Table 2 ).

Table 2 - Distribution of undergraduate students who practiced self-medication (76) according to their main pain and its characteristics (site, intensity and duration). Goiania, Brazil, 2009

\begin{tabular}{|c|c|c|c|}
\hline \multirow{2}{*}{ Variables } & \multicolumn{3}{|c|}{ Undergraduate students } \\
\hline & $\mathbf{n}$ & $(\%)$ & $\mathbf{p}^{*}$ \\
\hline Site & & & $<0.005$ \\
\hline Head & 38 & 50.2 & \\
\hline Shoulders and Upper limbs & 7 & 9.2 & \\
\hline Lower limbs & 7 & 9.2 & \\
\hline Others & 20 & 26 & \\
\hline Back region & 4 & 5.4 & \\
\hline Intensity & & & $<0.05$ \\
\hline Mild (1-3) & 7 & 9.2 & \\
\hline Moderate (4-6) & 33 & 43.4 & \\
\hline Intense (7-9) & 33 & 43.4 & \\
\hline Worst pain possible (10) & 3 & 3.9 & \\
\hline Duration & & & $>0.05$ \\
\hline Less than 3 months & 14 & 18.5 & \\
\hline More than 3 months and less than 6 & 9 & 11.8 & \\
\hline From 6 months to 1 year & 13 & 17.1 & \\
\hline From 1 to 5 years & 22 & 28.9 & \\
\hline From 5 to 10 years & 10 & 13.2 & \\
\hline More than 10 years & 8 & 10.5 & \\
\hline
\end{tabular}

In relation to the source that influenced selfmedication, $54.1 \%$ of students checked the alternative: the student him/herself after obtaining information on the medication, and $33.9 \%$ checked the alternative: someone in the family suggested the medication $(33.9 \%)(p<0.001)$.

The main reasons that led students to selfmedicate were lack of time to go to a physician (50\%); the students' own knowledge helped to choose the medication and access to the drugstore clerk was faster and cheaper $(5.3 \%)(p<0.001)$.

Among the most frequently used analgesics, the following stood out: dipyrone (59.2\%) (pure or in association with other drugs), paracetamol (19.8\%) (pure or associated), nonsteroidal anti-inflammatory drugs (13.1\%), while $2.6 \%$ used acetylsalicylic acid and $7.9 \%$ others.

In relation to relief experienced with self-medication, the scores classified it as good ( $\mathrm{Md}=8.5 ; \mathrm{Q} 1=6, \mathrm{Q} 3=10,0$, $M I N=0, M A X=10)$. Two students $(1.3 \%)$ did not obtain relief from their pain $(p>0.05)$.

\section{Discussion}

Self-medication has been reported in national and international literature. However, considering the scarcity 
of studies addressing the prevalence of self-medication among university students when in situations of pain, we opted for comparing the results of this study with those that investigated self-medication in similar situations such as the study carried out at the Federal University of Alfenas (UNIFAL), MG, Brazil. It examined the prevalence of self-medication among 245 nursing, pharmacy and dentistry students and found that $90.6 \%$ of the students reported such a practice, while $54.8 \%$ associated this practice with pain ${ }^{(4)}$. These results contrasted with those found in a study conducted in Taiwa that investigated the knowledge and beliefs of 6,270 undergraduate students aged 15 to 30 years of age, both genders in different programs, concerning the use of medication and found that they rarely practiced self-medication ${ }^{(9)}$.

Self-medication in situations of pain was observed in a mixed population (university students and nonstudents) in a study developed in Spain(5). A total of $27.6 \%$ of the 1,964 participants (aged between 20 and 91 years old, both genders) practiced self-medication, which contrasted with a prevalence of $64 \%$ observed among 270 individuals with an average age of 39.8 years, both genders, who displayed musculoskeletal pain in a study developed in Temuco, Chile(10). Even though the prevalence of self-medication in situations of pain observed in these studies is divergent, attention should be paid to the fact that some populations are composed of students from the health field who will eventually provide guidance on responsible self-medication based on WHO recommendations, contributing to the safety of those who experience pain.

In relation to the prevalent site of pain found in this study - the head - we observed that similar results were found in a study carried out with 742 people $(57.5 \%$ were women, aged between 18 and 70 years old) in Porto Alegre, RS, Brazil, $66.0 \%$ of the self-medication cases were related to headaches ${ }^{(11)}$, which is in agreement with another study carried out in Spain, which found a prevalence of $52.3 \%$ of individuals with headaches. In this last study, the pain's site was also significant in the practice of self-medication $(p<0.001)^{(5)}$.

There are few studies measuring pain in people who practice self-medication. From this perspective, one has to keep in mind that measuring pain is an essential element in the implementation, replacement or complementation of analgesic therapies in situations of pain $^{(12)}$. In Spain, people who practiced self-medication reported mild to moderate pain $(p<0.01)^{(5)}$. In a study carried out in Michigan, USA, the choices of 723 people to treat pain were investigated and more than $75 \%$ of them self-medicated with non-opioids for moderate pain $(A=5.77)^{(13)}$. Such results are similar to those found in this study. No studies addressing intensity of pain and self-medication intended to treat pain were found in Brazil.

Self-medication intended to treat pain is a little investigated subject, however a study carried out in Sweden with 1,806 individuals aged between 25 and 74 years of age investigated the impact of chronic pain on health care and observed that $14.9 \%$ of people with chronic pain practiced self-medication ${ }^{(14)}$. In our study, self-medication was higher than in the study carried out in Sweden (69.7\%).

The highest concentration of students who reported self-medication in our study was among $2^{\text {nd }}$ and $5^{\text {th }}$ year students. Such findings allowed us to infer that the pharmacology course administered in the $2^{\text {nd }}$ year did not interfere with self-medication, however, the experience acquired by the students in the $5^{\text {th }}$ year might have influenced the higher prevalence of self-medication among students to treat pain. These data differ from the results found in a study developed in UNIFAL where selfmedication intensified in the $7^{\text {th }}$ semester, compared to the first $(p<0.01)^{(4)}$.

The nursing program is mostly attended by women and that is why self-medication is prevalent among the female gender, which represents a limitation of this study. Divergent results were found among other studies: in Spain, a higher frequency of self-medication was found among women $(p<0.001)^{(5)}$; in Portugal, a significant association was found among people with an average age of 46 years old between self-medication and gender and it was most prevalent among men $(p<0.031)^{(15)}$; in Chile, a study carried out with individuals of an average age of 39.8 years old, did not find significant association between these variables ${ }^{(10)}$.

In Brazil, studies indicate that women are those who most frequently practice self-medication. The profile of self-medication in a city in the South of the country (average age of 30.3 years old) indicated that $65 \%$ of women practice self-medication against $44.9 \%$ of men ${ }^{(16)}$. Significant association between self-medication and gender was found in Bambuí, MG, Brazil and it was most prevalent among women $(p<0.0001)^{(6)}$.

In this study, self-medication was prevalent among students from the socioeconomic classes A1 (15.8\%) and A2 (29\%) (Monthly salaries between 5,703.76 and $3,846.31$ dollars) ( $p>0.05)$. In the city of Porto Alegre, RS, Brazil, most of the people who self-medicate had a monthly income more than three times the minimum 
wage (U\$ 615.29)(11). In Chile, a significant difference between self-medication and the various socioeconomic strata was found: $72 \%$ of those in the low socioeconomic class practiced self-medication $(p<0.0001)^{(10)}$.

The fact that those who provided guidance concerning self-medication were professionals not qualified to provide information on the rational use of over-the-counter drugs drew our attention. Such a fact may lead to the inappropriate treatment of pain, posing risks to the population's health. Similar results were found in Porto Alegre, RS, Brazil where $57.14 \%$ of people chose their medications based on previous experiences when complaints were similar to the current one, and $53.8 \%$ reported being influenced by friends and relatives ${ }^{(11)}$. The epidemiological profile of self-medication in Brazil shows that $51 \%$ of people practiced self-medication based on suggestions of non-qualified people and $40 \%$ on previous prescriptions(3). In Portugal, $50 \%$ of the medication used in self-medication was recommended by a pharmacist and $1.4 \%$ by a nurse ${ }^{(15)}$.

The nursing program at the Federal University of Goiás requires full time dedication, thus the high prevalence of nursing students who justified selfmedication due to lack of time to go to a physician might be explained by the fact they spend much time at school, involved in academic activities, research and extension activities and do not have time to seek health care. One has to keep in mind that even though students can be cared for in the very services where they develop their care practice, professionals are not always available to expeditiously care for them.

From this perspective, this study's results can be compared to those developed in João Pessoa, PB, Brazil. Self-medication was investigated in 102 nursing students and $75 \%$ were women, $56 \%$ practiced self-medication because they felt confident with knowledge acquired during the undergraduate program and $19 \%$ because they did not have time to go to the physician ${ }^{(17)}$. Similar results were found in Pakistan among 572 undergraduate students with an average of 21 years. The main reasons that led to selfmedication were self-experience with symptoms help to choose the medication (50.1\%) and symptoms are banal and dispense with medical care $(48.3 \%)^{(18)}$.

The most frequently used drug in Chile for selfmedication to alleviate musculoskeletal pain was dipyrone $(30.6 \%)$, followed by piroxicam $(20.7 \%)$ and acetylsalicylic acid $(15.6 \%)^{(10)}$. In the United States of America, 34\% used paracetamol, 33\% ibuprofen, 16\% acetylsalicylic acid and $15 \%$ opioids such as codeine, tramadol and morphine ${ }^{(13)}$. In Brazil, this study's results are similar to those found in Alfenas, MG in which $31.3 \%$ of the participants choose dipyrone, $15.9 \%$ paracetamol, $14.2 \%$ NSAIDs, and 5.6\% acetylsalicylic acid(4). The use of dipyrone and paracetamol as the main medications chosen by the nursing students to relieve pain is a concern, especially in relation to headaches, because the prolonged use of these drugs without medical followup can lead to pain becoming chronic and generate disastrous consequences and adverse side effects.

No studies evaluating pain relief through selfmedication were found in Brazil. In Spain, $86.6 \%$ of people reported having obtained good pain relief through self-medication(5), which corroborates this study's results. Pain relief was measured in the United States of America on a scale of $0 \%$ to $100 \%$ and moderate relief was observed $(45 \%)^{(13)}$. It is worth noting that the momentary relief of pain obtained through self-prescribed medication can lead people to postpone appropriate and early treatment, which contributes to the painful experience becoming chronic while co-morbidities may result from prolonged experience of pain.

\section{Conclusions}

Self-medication is frequent among undergraduate nursing students and the prevalence (38.8\%) of this practice was higher than that observed in similar studies. The characterization of pain self-reported by students showed that pain was moderate, predominantly chronic and located in the head.

The students were young, predominantly female from socioeconomic class A. They practiced selfmedication based on their own information and suggestions from relatives and the main reason that led them to practice self-medication was lack of time to go to a physician.

The most frequently used analgesics were dipyrone and paracetamol while relief obtained through them was classified as good. Even though the medications used by the students do not require a medical prescription, the irrational use of these drugs can cause disastrous side effects. Furthermore, the palliative treatment of pain can delay a correct diagnosis and appropriate treatment, which may lead to pain becoming chronic.

\section{References}

1. Paulo LG, Zanini AC. Automedicação no Brasil. Rev Assoc Méd Bras. 1988;34:69-75.

2. World Health Organization (WHO). The role of the pharmacist in self-medication and self-care. Genebra: 
WHO; 1998. (WHO/DAP/09.13).

3. Arrais PSD, Coelho HLL, Batista MCDS, Carvalho ML, Righi RE, Arnau JM. Perfil da automedicação no Brasil. Rev Saúde Pública. 1997;31(1):71-7.

4. Damasceno DD, Terra FS, Zanetti HHV, D'Andréia ED, Silva HLR, Leite JA. Automedicação entre graduandos de enfermagem, farmácia e odontologia da Universidade Federal de Alfenas. REME- Rev Min Enferm. 2007;11(1):48-52.

5. Bassols A, Bosch F, Baños J-E. How does the General population treat their pain? A survey in Catalonia, Spain. J Pain Symptom Manage. 2002;23(4)318-28.

6. Loyola AI Filho, Uchoa E, Guerra HL, Firmo JOA, Lima-Costa MF. Prevalência e fatores associados à automedicação: resultados do projeto Bambuí. Rev Saúde Pública. 2002 fevereiro;36(1):55-62.

7. Paredes NP, Miasso AI, Tirapelli CR. Consumo de benzodiazepinos sem prescrição médica entre estudantes do primeiro ano da escola de enfermagem da Universidade de Guayaquil, Equador. Rev. Latino-Am. Enfermagem. 2008 maio-junho;16(especial):634-9.

8. Merskey $\mathrm{H}$, Bogduk N. Classification of chronic pain: descriptions of sexuality e sexual adjustment of patients with chronic pain. Disabil Reabil. 1998;20(9):317-29.

9. Hsiao FY, Lee JA, Huang WF, Chen SM, Chen HY. Survey of Medication Knowledge and behaviors among college students in Taiwan. Am J Pharm Educ. 2006;70(2):1-7.

10. Riedemann GJP, Illesca MP, Droghettir J. Automedicacíon en individuos de la Région de la Araucanía con problemas musculoesqueléticos. Rev Méd Chile. $2001 ; 129(6): 647-52$.

11. Vitor RS, Lopes CP, Menezes HS, Kerkhoff CE. Padrão de consumo de medicamentos sem prescrição médica na cidade de Porto Alegre, RS. Ciênc Saúde Colet. 2008; 13(supl):737-43.

12. Sousa FAEF. Dor: o quinto sinal vital. Rev. LatinoAm. Enfermagem. 2002 maio-junho; 10(3):446-7.

13. Vallerand $\mathrm{AH}$, Fouladbakhsh $\mathrm{J}$, Templin $\mathrm{T}$. Patients' choices for the self-treatment of pain. Appl Nurs Res. 2005;18:90-6.

14. Andersson HI, Ejlertsson G, Leden I, Scherstén B. Impact of chronic pain on health care seeking, self care, and medication. Results from a population-based Swedish study. J Epidemiol Commun Health. 1999;53:503-9.

15. Mendes $Z$, Martins AP, Miranda AC, Soares MA, Ferreira AP, Nogueira A. Prevalência da automedicação na população urbana portuguesa. Rev Bras Ciênc Farm. 2004;40(1):21-5.

16. Vilarino JF, Soares IC, Silveira CM da, Rödel APP, Bortoli R, Lemos RR. Perfil da automedicação em município do Sul do Brasil. Rev Saúde Pública. 1998; 32(1):43-9.

17. Cerqueira GS, Diniz MFFM, Lucena GT, Dantas AF, Lime GMB. Perfil da automedicação em acadêmicos de enfermagem na cidade de João Pessoa. Conceitos. 2004/2005:123-6.

18. Zafar SN, Syed R, Sana W, Zubairi AJ, Vaqar T, Shaikh $M$, et al. Self-medication amongst University Students of Karachi: Prevalence, Knowledge and Attitudes. J Pakistan Med Assoc. 2008;58(4):214-7. 